\title{
Catalytic Ethylene Oligomerization over Ni/Al-HMS: A Key Step in Conversion of Bio-Ethanol to Higher Olefins
}

\author{
Yanyong Liu
}

Research Institute of Energy Frontier, National Institute of Advanced Industrial Science and Technology (AIST), AIST Tsukuba West, 16-1 Onogawa, Tsukuba, Ibaraki 305-8569, Japan; yy.ryuu@aist.go.jp; Tel.: +81-29-861-4826

Received: 12 October 2018; Accepted: 8 November 2018; Published: 12 November 2018

\begin{abstract}
Al-modified hexagonal mesoporous silica (HMS) materials were synthesized using dodecylamine as a template according to the methods reported in the literature. FT-IR spectra proved that $\mathrm{Al}^{3+}$ ions entered in the HMS framework in Al-HMS (prepared by sol-gel reaction) but $\mathrm{Al}^{3+}$ ions existed in the extra-framework in $\mathrm{Al} / \mathrm{HMS}$ (prepared by post-modification). $\mathrm{NH}_{3}-\mathrm{TPD}$ indicated that either Al-HMS or Al/HMS had solid acid sites on the surface, and the acidic strength of $\mathrm{Al} / \mathrm{HMS}$ was stronger than that of Al-HMS. For ethylene oligomerization at $200{ }^{\circ} \mathrm{C}$ under $1 \mathrm{MPa}$, $\mathrm{Ni} / \mathrm{Al}-\mathrm{HMS}$ showed an ethylene conversion of $96.3 \%$, which was much higher than that over $\mathrm{Ni} / \mathrm{Al} / \mathrm{HMS}$ (45.6\%). The selectivity for $\mathrm{C}_{4} \mathrm{H}_{8}, \mathrm{C}_{6} \mathrm{H}_{12}, \mathrm{C}_{8} \mathrm{H}_{16}$, and $\mathrm{C}_{8+}$ was $37.7 \%, 24.5 \%, 24.0 \%$, and $9.1 \%$ for ethylene oligomerization over Ni/Al-HMS, respectively. Ni/Al-MCM-41, which has been reported as an effective catalyst for ethylene oligomerization in the literature, showed a high ethylene conversion $(95.2 \%)$ similar to that of $\mathrm{Ni} / \mathrm{Al}-\mathrm{HMS}$ in this study. However, the selectivity for $\mathrm{C}_{8} \mathrm{H}_{16}$ over Ni/Al-MCM-41 (16.3\%) was lower than that over Ni/Al-HMS (24.0\%) in the ethylene oligomerization. For ethanol dehydration at $300{ }^{\circ} \mathrm{C}$ under $1 \mathrm{MPa}$, a commercial H-ZSM- 5 catalyst showed a high ethylene yield (91.2\%) after reaction for $24 \mathrm{~h}$ using a feed containing $90 \mathrm{wt} . \%$ ethanol and $10 \mathrm{wt} . \%$ water. In this study, a two-step process containing two fixed-bed reactors and one cold trap was designed to achieve the direct synthesis of higher olefins from bio-ethanol. The cold trap was used to collect the water formed from ethanol dehydration. By using H-ZSM-5 as a catalyst for ethanol dehydration in the first reactor and using Ni/Al-HMS as a catalyst for ethylene oligomerization in the second reactor, higher olefins were continuously formed by feeding a mixture containing $90 \mathrm{wt} . \%$ ethanol and $10 \mathrm{wt} . \%$ water. The yields of higher olefins did not decrease after reaction for $8 \mathrm{~h}$ in the two-step reaction system.
\end{abstract}

Keywords: bio-ethanol; dehydration; ethylene; oligomerization; higher olefins; Ni; Al-modified mesoporous silica

\section{Introduction}

The conversion of biomass to liquid fuels has become an important research field because biomass utilization has an effect in reducing greenhouse gas emission [1]. Bio-ethanol is produced in a large scale from sugary, starchy, and lignocellulosic biomasses by yeast fermentation [2]. Currently, bio-ethanol accounts for above $90 \%$ of worldwide biofuel production. Bio-ethanol is mainly used as fuel for automobiles by blending with gasoline. Although bio-ethanol is an attractive fuel; the needs of transportation fuel for automobiles will be reduced from now due to the popularization of electric vehicle and hydrogen-fueled car. Hence, bio-ethanol is expected to be in surplus in future years. It is necessary to develop new technologies to utilize the surplus bio-ethanol. Production of hydrogen by the steam reforming of bio-ethanol is an available technology [3]. However, hydrogen is expected 
to be obtained from water electrolysis using the electric power from renewable energy. Recently, the technology for converting bio-ethanol to higher olefins has received extensive interests because the higher olefins can be used for producing jet fuel and fine chemicals $[4,5]$.

Ethylene is a platform in conversion of bio-ethanol to higher olefins [6-8]. At first, ethylene is obtained through the hydration of bio-ethanol. Then, the formed ethylene is converted to higher olefins through the oligomerization of ethylene. Highly active catalyst for ethylene oligomerization is the key technology in conversion of bio-ethanol to higher olefins. Acid strength and pore size of the catalyst greatly influence the product distribution in ethylene oligomerization [9]. Acidic zeolites (H-ZSM-5 and H-Beta zeolite) usually form $\mathrm{C}_{3}-\mathrm{C}_{4}$ olefins from ethylene oligomerization due to strong acidity and small micropores [10-12]. Also, the direct synthesis of $\mathrm{C}_{3} \mathrm{H}_{6}$ from bio-ethanol has been reported in the literature because direct synthesis has a high efficiency in industry [13].

Mesoporous silica materials (such as MCM-41, SBA-15, HMS, and so on) have high thermal stability (above $850{ }^{\circ} \mathrm{C}$ ), large surface area (about $1000 \mathrm{~m}^{2} \mathrm{~g}^{-1}$ ), and uniform-sized pores [14-17]. Hexagonal mesoporous silica (HMS) can be easily synthesized using dodecylamine at room temperature [17]. Also, transition metal cations (such as $\mathrm{Al}^{3+}, \mathrm{Ti}^{4+}$, and so on) can be uniformly incorporated into the HMS framework with high content [18]. Al-HMS has physical and textural properties similar to those of Al-MCM-41 but has substantially higher Bronsted acidity [19]. Because HMS has these advantages among mesoporous silica materials, HMS-based materials have been used as catalysts or as supports in the catalysis field [16-29].

Bifunctional catalysts containing $\mathrm{Ni}$ and solid acid are regarded as the most promising catalysts for the synthesis of $\mathrm{C}_{6+}$ higher olefins by ethylene oligomerization. The design of a large pore in a catalyst is an important task in the synthesis of higher olefins. The zeolites (H-ZSM-5 and H-Beta zeolite) with large cages and hierarchical-type porosity had been synthesized and they formed $\mathrm{C}_{6+}$ higher olefins from ethylene oligomerization [10]. However, coke was formed on the surface of acidic zeolite during the reaction due to the strong acidity of zeolite $[10,12]$. The coke blocked the pores of zeolite and caused the catalyst deactivation during the reaction. In order to overcome the catalyst deactivation, weak solid acids (such as amorphous silica-alumina, sulfated alumina, and so on) were used as supports for $\mathrm{Ni}$ in the ethylene oligomerization [30-32]. A relatively high reaction temperature was necessary to obtain a high ethylene conversion because using a weak solid acid increased the catalyst stability but decreased the reaction speed. Because mesoporous silica materials have uniformed large pores and weak solid acidity, catalysts containing $\mathrm{Ni}$ and mesoporous silica materials have been reported as effective catalysts in the synthesis of higher olefins by ethylene oligomerization [33-38]. $\mathrm{Ni} / \mathrm{Al}-\mathrm{MCM}-41$ and Ni/Al-SBA-15 selectively formed $\mathrm{C}_{4} \mathrm{H}_{8}, \mathrm{C}_{6} \mathrm{H}_{12}, \mathrm{C}_{8} \mathrm{H}_{10}$, and $\mathrm{C}_{10} \mathrm{H}_{20}$ from ethylene oligomerization (due to the large pores of MCM-41 and SBA-15), and they showed high catalytic stability because no coke was formed on the catalyst surface during the reaction (due to the weak acidity of Al-MCM-41 and Al-SBA-15) [37,38].

The catalytic ability of Al-modified HMS has not been investigated for the oligomerization of ethylene in the literature. Moreover, there is no report of the direct synthesis of $\mathrm{C}_{4}{ }^{+}$higher olefins from bio-ethanol in the literature. In the present study, the catalysts containing Ni and Al-modified HMS have been used for ethylene oligomerization comparing with Ni/Al-MCM-41. Also, a continuous two-step process (combining ethanol dehydration and ethylene oligomerization) has been designed to achieve the direct production of higher olefins from bio-ethanol.

\section{Results and Discussion}

\subsection{Characterization of Catalysts}

Figure 1 shows the X-ray diffraction (XRD) patterns of mesoporous silica samples after calcining at $550{ }^{\circ} \mathrm{C}$ for $4 \mathrm{~h}$. Al-MCM-41 showed a strong peak at about 2.5 degrees and two weak peaks at 4-6 degrees in the XRD pattern. The strong peak was corresponded to the $\left(\begin{array}{lll}1 & 0 & 0\end{array}\right)$ plane, and two weak peaks were corresponded to the $\left(\begin{array}{lll}1 & 1 & 0\end{array}\right)$ plane and the $\left(\begin{array}{lll}2 & 0 & 0\end{array}\right)$ plane [14]. This pattern implied 
the existence of long-range linear mesoporous structure in Al-MCM-41 [15]. HMS exhibited a strong peak corresponding to the (100) plane at about 2.5 degrees and a broad band close to 5.3 degrees. This pattern implied the existence of wormhole mesoporous structure in HMS [16]. By calculating from the degree of (100) plane in the XRD pattern, HMS had a $d_{100}$ spacing value of $35.3 \AA$. The value of $\mathrm{d}_{100}$ spacing in Al-HMS was lower than that of HMS because small $\mathrm{Al}^{3+}$ ions were incorporated in the HMS framework. On the other hand, the value of $d_{100}$ spacing in Al/HMS was similar to that of HMS because $\mathrm{Al}^{3+}$ ions did not enter in the HMS framework.

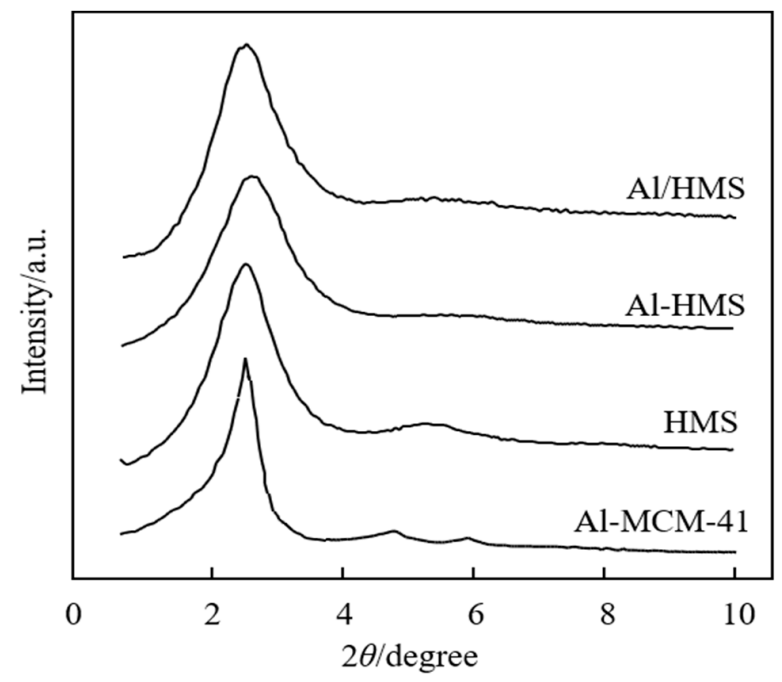

Figure 1. X-ray diffraction (XRD) patterns of mesoporous silica samples after calcining at $550{ }^{\circ} \mathrm{C}$ for $4 \mathrm{~h}$.

Figure 2 shows the FT-IR spectra of various HMS-based samples after calcining at $550{ }^{\circ} \mathrm{C}$ for $4 \mathrm{~h}$. In the FT-IR spectrum of HMS, the peak at $1090 \mathrm{~cm}^{-1}$ was assigned to the asymmetric stretching of $\mathrm{Si}-\mathrm{O}-\mathrm{Si}$ and the peak at $810 \mathrm{~cm}^{-1}$ was assigned to the stretching of the tetrahedral $\mathrm{SiO}_{4}{ }^{4-}$ structural units. HMS did not show a peak at $960 \mathrm{~cm}^{-1}$ in the FT-IR spectrum. Al-HMS showed a peak at $960 \mathrm{~cm}^{-1}$ in the FT-IR spectrum. Because the peak at $960 \mathrm{~cm}^{-1}$ was assigned to the stretching Si-O vibration with the neighborhood metal ions, this peak had been used to characterize the incorporation of metal ions in the silica framework [39]. The Al/HMS sample prepared by post-modification did not show a peak at $960 \mathrm{~cm}^{-1}$ in the FT-IR spectrum. Hence, $\mathrm{Al}^{3+}$ ions entered into the HMS framework in Al-HMS but existed at the outside of the HMS framework in Al/HMS.

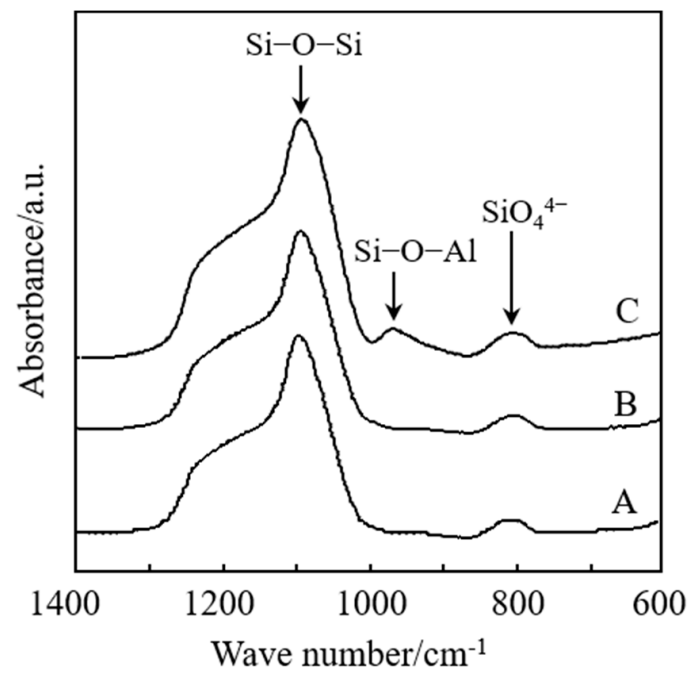

Figure 2. FT-IR spectra of various HMS-based samples after calcining at $550{ }^{\circ} \mathrm{C}$ for $4 \mathrm{~h}$. (A): HMS; (B): Al/HMS; (C): Al-HMS. 
Figure 3 shows the $\mathrm{NH}_{3}$-TPD profiles of various samples after calcining at $550{ }^{\circ} \mathrm{C}$ for $4 \mathrm{~h}$. The $\mathrm{NH}_{3}$-TPD measurement was used to evaluate the acidic strength of solid acids. The absorbed $\mathrm{NH}_{3}$ molecules desorbed from weak solid acids at low temperatures and desorbed from strong solid acids at high temperatures. As shown in Figure 3, no peak could be observed in the $\mathrm{NH}_{3}$-TPD profile of HMS, indicating that HMS did not have any acid sites on the surface. Al-HMS had solid acid sites on the surface because a peak at $220^{\circ} \mathrm{C}$ was observed in the $\mathrm{NH}_{3}$-TPD profile. The maximum temperature of $\mathrm{NH}_{3}$ desorption of $\mathrm{Al} / \mathrm{HMS}$ was higher than that of Al-HMS in the $\mathrm{NH}_{3}$-TPD profiles, implying that the acid sites in Al/HMS were stronger than those in Al-HMS. Because $\mathrm{Al}^{3+}$ ions were introduced in Al-HMS at the preparation step, $\mathrm{Al}^{3+}$ located uniformly in the HMS framework in Al-HMS. On the other hand, because $\mathrm{Al}^{3+}$ ions were introduced in $\mathrm{Al} / \mathrm{HMS}$ by post-modification, the $\mathrm{Al}^{3+}$ ions existed at the extra-framework in $\mathrm{Al} / \mathrm{HMS}$. It has been reported that the extra-framework $\mathrm{Al}^{3+}$ ions had stronger acidity compared with the intra-framework $\mathrm{Al}^{3+}$ ions in Al-containing MCM-41 catalysts [40]. H-ZSM- 5 exhibited two peaks at 220 and $450{ }^{\circ} \mathrm{C}$ in the $\mathrm{NH}_{3}$-TPD profile. Hence, $\mathrm{H}-\mathrm{ZSM}-5$ had both weak solid acid and strong solid acid on the surface. The peak at the highest temperature in the $\mathrm{NH}_{3}$-TPD profile corresponds to the strongest acid sites on the solid surface. H-ZSM-5 is a strong solid acid because the strongest acid sites determine the ability of a solid acid catalyst. According to the peak position at the maximum temperature in the $\mathrm{NH}_{3}$-TPD profiles, the acidic strength of various samples was in the order of H-ZSM-5 >> Al/HMS > Al-HMS > HMS (no acidity).

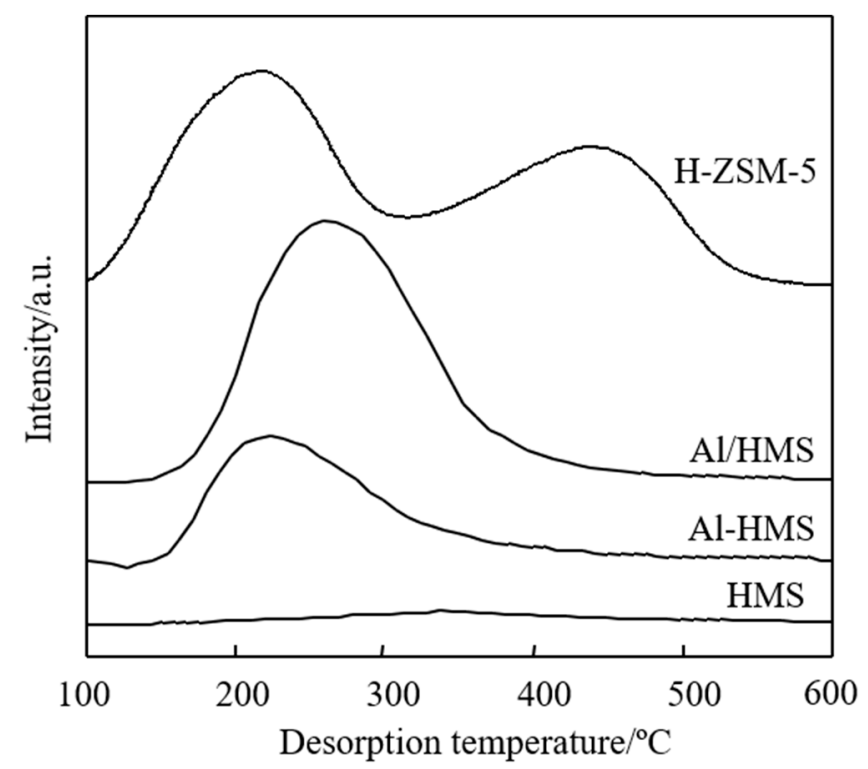

Figure 3. $\mathrm{NH}_{3}$-TPD profiles of various samples after calcining at $550{ }^{\circ} \mathrm{C}$ for $4 \mathrm{~h}$.

\subsection{Development of Catalyst for Ethylene Oligomerization}

Table 1 shows the reaction results of ethylene oligomerization over various catalysts containing $\mathrm{Ni}$ and solid acid. Ni/H-ZSM-5 showed a high ethylene conversion of $90.7 \%$ at a low reaction temperature of $150{ }^{\circ} \mathrm{C}$ due to strong solid acidity of $\mathrm{H}-\mathrm{ZSM}-5$. Ni/H-ZSM- 5 formed $\mathrm{C}_{4} \mathrm{H}_{8}$ as the major product and did not form any olefins larger than $\mathrm{C}_{6} \mathrm{H}_{12}$. Also, Ni/H-ZSM-5 formed a relatively large amount of $\mathrm{C}_{3} \mathrm{H}_{6}$ from the cracking of $\mathrm{C}_{6} \mathrm{H}_{12}$ formed in the reaction. Hence, Ni/H-ZSM-5 is not a suitable catalyst for producing higher olefins from ethylene oligomerization. Three catalysts containing $\mathrm{Ni}$ and mesoporous silica used in this study produced higher olefins larger than $\mathrm{C}_{6} \mathrm{H}_{12}$ from the ethylene oligomerization at $200{ }^{\circ} \mathrm{C}$. Ni/Al-HMS showed an ethylene conversion of $96.3 \%$, which was much higher than that over $\mathrm{Ni} / \mathrm{Al} / \mathrm{HMS}(45.6 \%)$ for the reaction. In $\mathrm{Al}-\mathrm{HMS}, \mathrm{Al}^{3+}$ ions entered in the positions of $\mathrm{Si}^{4+}$ ions in the framework and existed in the neighborhood of $\mathrm{Si}^{4+}$ ion. In $\mathrm{Al} / \mathrm{HMS}$, $\mathrm{Al}^{3+}$ ions did not enter in the positions of $\mathrm{Si}^{4+}$ ions and existed far from $\mathrm{Si}^{4+}$ ion. Hence, the existence of $\mathrm{Al}^{3+}$ ions in the neighborhood of $\mathrm{Si}^{4+}$ ions is important for improving the catalytic activity of 
Ni-based catalyst in the ethylene oligomerization. Ni/Al-MCM-41 has been reported as an effective catalyst for the synthesis of higher olefins from ethylene oligomerization $[34,38]$. As shown in Table 1 , $\mathrm{Ni} / \mathrm{Al}-\mathrm{MCM}-41$ showed an ethylene conversion of $95.2 \%$ at $200{ }^{\circ} \mathrm{C}$. Ni/Al-MCM-41 showed a $\mathrm{C}_{8} \mathrm{C}_{16}$ selectivity of $16.3 \%$, which was lower than that over Ni/Al-HMS (24.0\%) for the reaction.

Table 1. Reaction results of ethylene oligomerization over various catalysts containing Ni and solid acid $^{\mathrm{a}}$.

\begin{tabular}{ccccccc}
\hline \multirow{2}{*}{ Catalyst $^{\mathbf{b}}$} & \multirow{2}{*}{ Conversion (\%) } & \multicolumn{5}{c}{ Selectivity (\%) } \\
\cline { 3 - 7 } & & $\mathbf{C}_{\mathbf{4}} \mathbf{H}_{\mathbf{8}}$ & $\mathbf{C}_{\mathbf{6}} \mathbf{H}_{\mathbf{1 2}}$ & $\mathbf{C}_{\mathbf{8}} \mathbf{C}_{\mathbf{1 6}}$ & $\mathbf{C}_{\mathbf{8 +}}$ & Others $^{\mathbf{c}}$ \\
\hline $\mathrm{Ni} / \mathrm{Al}-\mathrm{HMS}$ & 96.3 & 37.7 & 24.5 & 24.0 & 9.1 & 2.9 \\
$\mathrm{Ni} / \mathrm{Al} / \mathrm{HMS}$ & 45.6 & 30.3 & 19.4 & 33.7 & 11.8 & 3.8 \\
$\mathrm{Ni} / \mathrm{Al}-\mathrm{MCM}-41$ & 95.2 & 45.6 & 28.5 & 16.3 & 6.2 & 2.6 \\
$\mathrm{Ni} / \mathrm{H}-\mathrm{ZSM}-5^{\mathrm{d}}$ & 90.7 & 77.6 & 1.1 & 0 & 0 & 19.2 \\
\hline
\end{tabular}

a Reaction conditions: catalyst amount: 2 g; feed gas flow rate: $60 \mathrm{~mL} \mathrm{~min}^{-1}$; feed gas composition: $90 \% \mathrm{C}_{2} \mathrm{H}_{4}+$ $10 \%$ Ar; reaction temperature: $200{ }^{\circ} \mathrm{C}$; reaction pressure: $1 \mathrm{MPa} .{ }^{\mathrm{b}} \mathrm{Ni}$ content: $2 \mathrm{wt} . \% .{ }^{\mathrm{c}}$ Others: $\mathrm{C}_{3} \mathrm{H}_{6}, \mathrm{C}_{2} \mathrm{H}_{6}$, and so on. ${ }^{\mathrm{d}}$ Reaction at $150^{\circ} \mathrm{C}$.

Figure 4 shows the dependence of Ni content in Ni/Al-HMS for the oligomerization of ethylene. Al-MHS (without Ni) showed a very low ethylene conversion of $2.2 \%$, indicating that the weak acidity of Al-HMS just had a very low catalytic activity for ethylene oligomerization at $200{ }^{\circ} \mathrm{C}$. The ethylene conversion greatly increased by introducing Ni in Al-HMS, suggesting that the Ni sites in Ni/Al-HMS were the main active sites in the ethylene oligomerization. The ethylene conversion increased with increasing Ni content from 0 to $2 \mathrm{wt} . \%$, and then slightly decreased at above $2 \mathrm{wt} . \%$ in $\mathrm{Ni} / \mathrm{Al}-\mathrm{HMS}$. It has been reported that the $\mathrm{Ni}$ species exchanged into the pores of mesoporous silica are catalytically active species and the $\mathrm{Ni}$ species loaded on the mesoporous silica are inactive for the ethylene oligomerization on Ni/Al-MCM-41 [41]. Hence, about $2 \mathrm{wt} . \% \mathrm{Ni}$ could be exchanged into the pores of Al-HMS and the excessive Ni was loaded on the Al-HMS surface when the Ni content was larger than $2 \mathrm{wt} . \%$ in Ni/Al-HMS. The selectivity for $\mathrm{C}_{4} \mathrm{H}_{8}$ decreased with increasing Ni content from 0 to $1.5 \mathrm{wt} . \%$ and almost did not change at above $1.5 \mathrm{wt} . \%$ in Ni/Al-HMS. On the contrary, the selectivity for $\mathrm{C}_{6} \mathrm{H}_{12}$ and the selectivity for $\mathrm{C}_{8} \mathrm{H}_{16}$ increased with increasing Ni content from 0 to $1.5 \mathrm{wt} . \%$ and almost did not change at above $1.5 \mathrm{wt} . \%$ in Ni/Al-HMS. Hence, $\mathrm{C}_{4} \mathrm{H}_{8}$ was the primary product and it converted to $\mathrm{C}_{6+}$ higher olefins during the reaction.

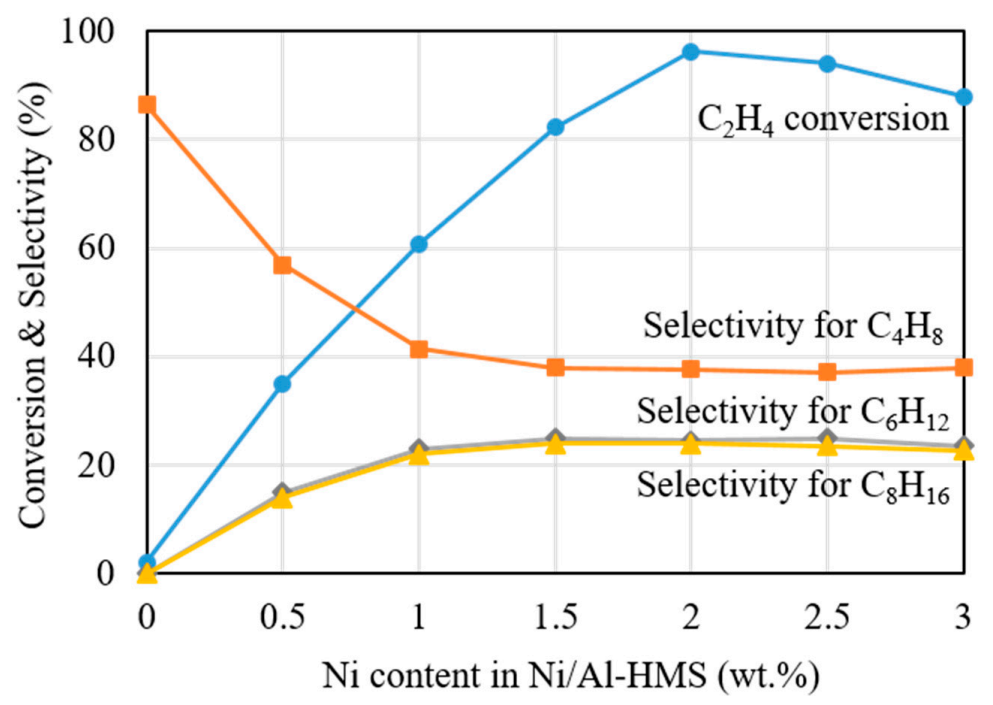

Figure 4. Dependence of Ni content in Ni/Al-HMS for the oligomerization of ethylene. Reaction conditions: same as those listed in Table 1. 
Figure 5 shows the reaction pathway of $\mathrm{C}_{8} \mathrm{H}_{16}$ formation in the oligomerization of ethylene on $\mathrm{Ni} / \mathrm{Al}-\mathrm{HMS}$. As discussed above, Ni sites are the main active sites for the ethylene oligomerization over Ni/Al-HMS. The oligomerization of ethylene on Ni is a Schulz-Flory type oligomerization. Any intermediate products formed during the reaction undergo further oligomerization (with ethylene) on $\mathrm{Ni}$ or desorption from $\mathrm{Ni}$ at the same time. Therefore, the products should obey a Schulz-Flory distribution with decreasing in the order of $\mathrm{C}_{4}>\mathrm{C}_{6}>\mathrm{C}_{8}>\mathrm{C}_{10}$. However, the selectivity for $\mathrm{C}_{8} \mathrm{H}_{16}$ was similar to the selectivity for $\mathrm{C}_{6} \mathrm{H}_{12}$ at each Ni content in Ni/Al-HMS (as shown in Figure 4). Hence, some other active species (except $\mathrm{Ni}$ ) improved the amount of $\mathrm{C}_{8} \mathrm{H}_{16}$ from the ethylene oligomerization over Ni/Al-HMS. As discussed above, although Al-HMS had acid sites on the surface (by introduction of $\mathrm{Al}^{3+}$ ions), the acidity of Al-HMS was weak and thus Al-HMS showed a very low activity for the ethylene oligomerization. Also, $\mathrm{C}_{4} \mathrm{H}_{8}$ formed from the ethylene dimerization was the primary product in the ethylene oligomerization over Ni/Al-HMS. Because $\mathrm{C}_{4} \mathrm{H}_{8}$ had a higher reactivity than ethylene, it can be assumed that the primary product $\mathrm{C}_{4} \mathrm{H}_{8}$ dimerized to $\mathrm{C}_{8} \mathrm{H}_{16}$ on the acid site of Al-HMS. On Ni/Al-HMS, $\mathrm{C}_{8} \mathrm{H}_{16}$ was formed not only from the reaction of $\mathrm{C}_{6} \mathrm{H}_{12}$ with $\mathrm{C}_{2} \mathrm{H}_{4}$ on Ni sites but also form the dimerization of $\mathrm{C}_{4} \mathrm{H}_{8}$ on acid sites of Al-HMS. The acid sites in Al-HMS improved the amount of $\mathrm{C}_{8} \mathrm{H}_{16}$ and caused a non-Schulz-Flory type distribution of the products in the oligomerization of ethylene over Ni/Al-HMS.

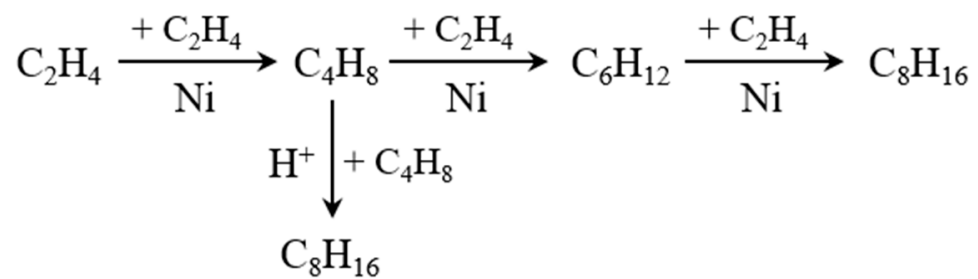

Figure 5. Reaction pathway of $\mathrm{C}_{8} \mathrm{H}_{16}$ formation in the oligomerization of ethylene on Ni/Al-HMS.

Figure 6 shows the illustration of Bronsted acid sites in Ni/Al-HMS. The Bronsted acid sites are formed on the $\mathrm{O}^{2-}$ ions which simultaneously bond with $\mathrm{Si}^{4+}$ ions and $\mathrm{Al}^{3+}$ ions in $\mathrm{Ni} / \mathrm{Al}-\mathrm{HMS}$. This model has been suggested in the literature for the oligomerization of ethylene over Ni/ Al-MCM-41 and Ni/Al-SBA-15 [35,37]. This is the reason that the introduction of $\mathrm{Al}^{3+}$ ions brought solid acid sites in Al-HMS. The Bronsted acid sites have been assumed as the active sites for the olefin dimerization. Proton-type ion-exchange resin, a type of solid catalyst containing only Bronsted acid (without Lewis acid), has been known as an effective catalyst for the olefin dimerization [42]. Also, the Bronsted acid sites in Ni/Al-MCM-41 have been reported as the active sites for the dimerization of $\mathrm{C}_{4} \mathrm{H}_{8}$ [35]. Furthermore, it has been reported that Al-HMS has physical and textural properties similar to those of MCM-41 but with substantially higher Bronsted acidity [19]. Hence, Al-HMS is expected to have a stronger ability for $\mathrm{C}_{4} \mathrm{H}_{8}$ dimerization compared with that of Al-MCM-41. This is the reason that the selectivity for $\mathrm{C}_{8} \mathrm{H}_{16}$ over Ni/Al-HMS was larger than that over Ni/Al-MCM-41 in the oligomerization of ethylene (as shown in Table 1).

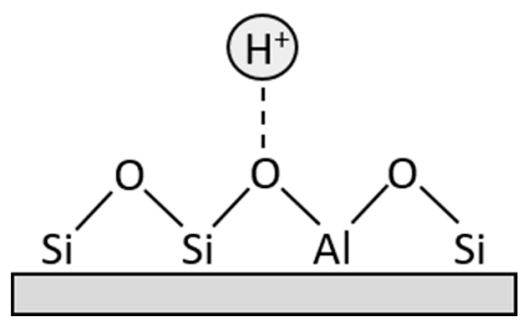

Figure 6. Illustration of Bronsted acid sites in Ni/ Al-HMS. 


\subsection{Catalytic Ethanol Dehydration over H-ZSM-5}

Bio-ethanol produced by the fermentation of biomass is a mixture of ethanol and water. Because ethanol and water form a binary azeotrope system containing $95.6 \mathrm{wt} . \%$ ethanol and $4.4 \mathrm{wt} . \%$ water, the conventional distillation cannot produce high-purity ethanol above $95.6 \mathrm{wt} . \%$. The direct use of hydrous ethanol to produce ethylene is an environmentally friendly method by avoiding a strenuous separation process. The development of catalyst for the dehydration of ethanol to ethylene has been researched for many years [43]. The recent researches focus on improvement of catalyst stability in diluted bio-ethanol and improvement of catalyst activity at low reaction temperatures $[6,7]$.

The dehydration of ethanol to ethylene is an acid-catalytic reaction which needs the existence of acid sites on the catalyst surface. Acidic zeolites, transition metal oxides, acidic clays, and heteropolyacids have been used in the dehydration of ethanol to ethylene [43]. Among various catalysts, acidic zeolite H-ZSM-5 is known as a highly active catalyst for the dehydration of ethanol [44]. Hence, we investigated a commercial H-ZSM-5 for the dehydration of ethanol in this study.

Table 2 shows the effect of reaction temperature in the dehydration of ethanol over H-ZSM- 5 . The data were obtained after reaction for $1 \mathrm{~h}$ at various reaction temperatures. The $\mathrm{C}_{2} \mathrm{H}_{5} \mathrm{OH}$ conversion was $64.8 \%$ and the selectivity for $\mathrm{C}_{2} \mathrm{H}_{4}$ was $75.6 \%$ for the reaction at a low temperature of $250{ }^{\circ} \mathrm{C}$. The selectivity for the by-product $\mathrm{C}_{2} \mathrm{H}_{5} \mathrm{OC}_{2} \mathrm{H}_{5}$ was high $(23.8 \%)$ at $250{ }^{\circ} \mathrm{C}$ but it greatly decreased with increasing reaction temperature from 250 to $325^{\circ} \mathrm{C}$. Both the $\mathrm{C}_{2} \mathrm{H}_{5} \mathrm{OH}$ conversion and the selectivity for $\mathrm{C}_{2} \mathrm{H}_{4}$ increased with increasing reaction temperature from 250 to $300{ }^{\circ} \mathrm{C}$. When the reaction was carried at a high temperature of $325^{\circ} \mathrm{C}$, the $\mathrm{C}_{2} \mathrm{H}_{5} \mathrm{OH}$ conversion continuously increased to $98.7 \%$ but the selectivity for $\mathrm{C}_{2} \mathrm{H}_{4}$ begun to decrease due to $\mathrm{CH}_{3} \mathrm{CHO}$ formation. In the dehydration of ethanol at $300{ }^{\circ} \mathrm{C}$, the $\mathrm{C}_{2} \mathrm{H}_{5} \mathrm{OH}$ conversion was $95.4 \%$ and the selectivity for $\mathrm{C}_{2} \mathrm{H}_{4}$ was $96.9 \%$, which gave a $\mathrm{C}_{2} \mathrm{H}_{4}$ yield of $92.4 \%$ for the dehydration of ethanol over $\mathrm{H}-\mathrm{ZSM}-5$.

Table 2. Effect of reaction temperature in the dehydration of ethanol over H-ZSM- 5 a .

\begin{tabular}{cccccc}
\hline \multirow{2}{*}{ Temperature $\left({ }^{\circ} \mathbf{C}\right)$} & \multirow{2}{*}{$\mathbf{C}_{\mathbf{2}} \mathbf{H}_{\mathbf{5}} \mathbf{O H}$ Conversion (\%) } & \multicolumn{5}{c}{ Yield (\%) } \\
\cline { 3 - 6 } & & $\mathbf{C}_{\mathbf{2}} \mathbf{H}_{\mathbf{4}}$ & $\mathbf{C}_{\mathbf{2}} \mathbf{H}_{\mathbf{5}} \mathbf{O C}_{\mathbf{2}} \mathbf{H}_{\mathbf{5}}$ & $\mathbf{C H}_{\mathbf{3}} \mathbf{C H O}$ & Others $^{\mathbf{b}}$ \\
\hline 250 & 64.8 & 75.6 & 23.8 & 0 & 0.6 \\
275 & 82.5 & 90.3 & 8.3 & 0.2 & 1.2 \\
300 & 95.4 & 96.9 & 1.4 & 0.4 & 1.3 \\
325 & 98.7 & 93.5 & 0.5 & 4.4 & 1.6 \\
\hline
\end{tabular}

${ }^{a}$ Reaction conditions: catalyst: $2 \mathrm{~g}$; liquid feed rate: $0.13 \mathrm{~g} \mathrm{~min}^{-1}$; liquid feed composition: $90 \mathrm{wt} . \% \mathrm{C}_{2} \mathrm{H}_{5} \mathrm{OH}+10$

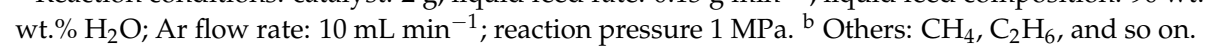

Equations (1)-(4) list the main reactions that occurred in the dehydration of ethanol on the solid acid catalysts. $\mathrm{C}_{2} \mathrm{H}_{4}$ was formed through the dehydration from one $\mathrm{C}_{2} \mathrm{H}_{5} \mathrm{OH}$ molecule (Equation (1)). $\mathrm{C}_{2} \mathrm{H}_{5} \mathrm{OC}_{2} \mathrm{H}_{5}$ was formed through the dehydration between two $\mathrm{C}_{2} \mathrm{H}_{5} \mathrm{OH}$ molecules (Equation (2)) [39]. At high reaction temperatures, the by-product $\mathrm{C}_{2} \mathrm{H}_{5} \mathrm{OC}_{2} \mathrm{H}_{5}$ decomposed to $\mathrm{C}_{2} \mathrm{H}_{5} \mathrm{OH}$ and $\mathrm{C}_{2} \mathrm{H}_{4}$ (Equation (3)) [8]. $\mathrm{CH}_{3} \mathrm{CHO}$ was formed at high temperatures through the dehydrogenation of ethanol (Equation (4)) [8].

$$
\begin{gathered}
\mathrm{C}_{2} \mathrm{H}_{5} \mathrm{OH}=\mathrm{C}_{2} \mathrm{H}_{4}+\mathrm{H}_{2} \mathrm{O} \\
2 \mathrm{C}_{2} \mathrm{H}_{5} \mathrm{OH}=\mathrm{C}_{2} \mathrm{H}_{5} \mathrm{OC}_{2} \mathrm{H}_{5}+\mathrm{H}_{2} \mathrm{O} \\
\mathrm{C}_{2} \mathrm{H}_{5} \mathrm{OC}_{2} \mathrm{H}_{5}=\mathrm{C}_{2} \mathrm{H}_{5} \mathrm{OH}+\mathrm{C}_{2} \mathrm{H}_{4} \\
\mathrm{C}_{2} \mathrm{H}_{5} \mathrm{OH}=\mathrm{CH}_{3} \mathrm{CHO}+\mathrm{H}_{2}
\end{gathered}
$$

Figure 7 shows the influence of water amount in feed for the dehydration of ethanol over H-ZSM-5. When a pure ethanol (without water) was fed for the reaction, the $\mathrm{C}_{2} \mathrm{H}_{4}$ yield almost did not decrease after reaction at $300{ }^{\circ} \mathrm{C}$ for $24 \mathrm{~h}$. Using a feed containing $90 \mathrm{wt} . \%$ ethanol and $10 \mathrm{wt} . \%$ water, the $\mathrm{C}_{2} \mathrm{H}_{4}$ yield was $92.4 \%$ after reaction for $1 \mathrm{~h}$ and the $\mathrm{C}_{2} \mathrm{H}_{4}$ yield decreased to $91.2 \%$ after reaction for 
$24 \mathrm{~h}$. By increasing water amount in feed from $10 \mathrm{wt} . \%$ to $50 \mathrm{wt} . \%$, the $\mathrm{C}_{2} \mathrm{H}_{4}$ yield after reaction for $1 \mathrm{~h}$ slightly decreased, and the $\mathrm{C}_{2} \mathrm{H}_{4}$ yield after reaction for $24 \mathrm{~h}$ obviously decreased during the reaction. A large amount of water in feed caused the catalyst deactivation in the dehydration of ethanol over H-ZSM-5.

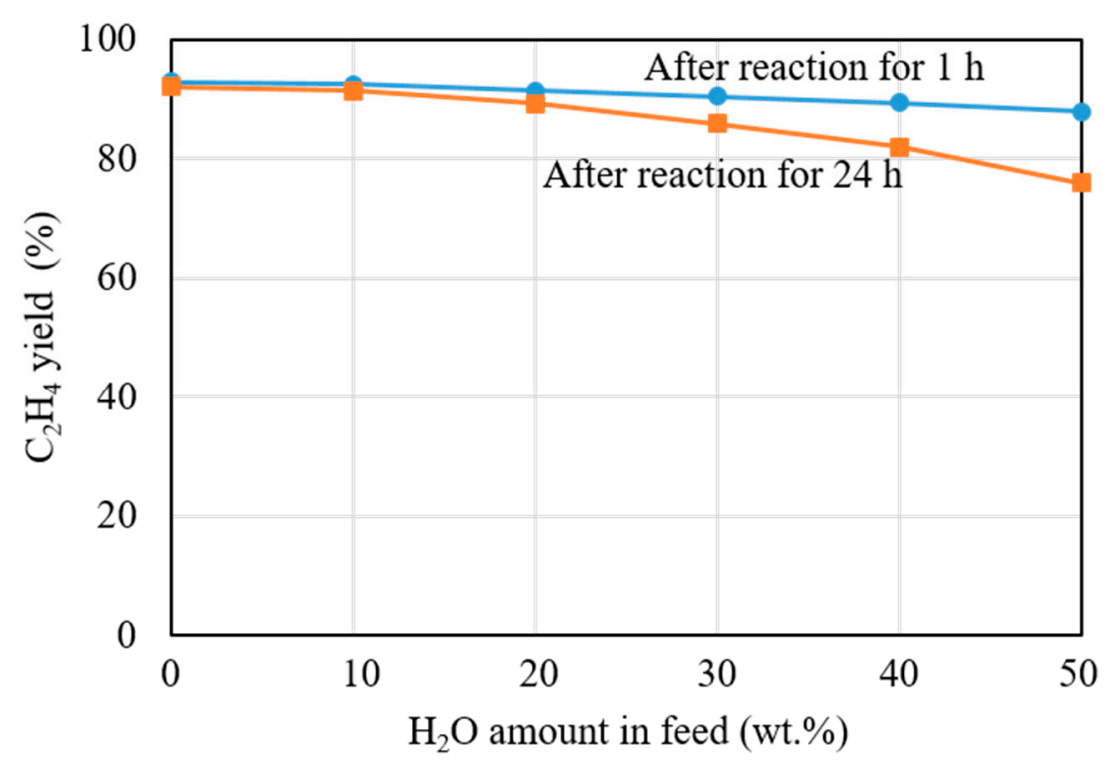

Figure 7. Influence of water amount in feed for the dehydration of ethanol over H-ZSM-5. Reaction

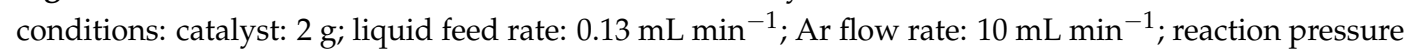
$1 \mathrm{MPa}$; reaction temperature: $300^{\circ} \mathrm{C}$.

The purpose of this study is designing a continuous process for the direct synthesis of higher olefins from bio-ethanol by combining ethanol dehydration and ethylene oligomerization, but is not developing a highly active catalyst for the dehydration of ethanol. Because an ethylene yield of $91.2 \%$ could be obtained after reaction for $24 \mathrm{~h}$ using a feed containing $90 \mathrm{wt} . \%$ ethanol and $10 \mathrm{wt} . \%$ water (as shown in Figure 7), commercial H-ZSM-5 had a high catalytic performance for the dehydration of hydrous ethanol at $300{ }^{\circ} \mathrm{C}$. Hence, we used the commercial H-ZSM- 5 as a catalyst for the dehydration of hydrous ethanol in the following part.

\subsection{Production of Higher Olefins from Hydrous Ethanol by Two-Step Process}

A two-step reaction system was designed in this study to achieve the direct synthesis of higher olefins from bio-ethanol by combining ethanol dehydration and ethylene oligomerization. H-ZSM-5 was used as a catalyst for the first step of ethanol dehydration, and Ni/Al-HMS was used as a catalyst for the second step of ethylene oligomerization.

Because the binary azeotrope system of ethanol and water contains $4.4 \mathrm{wt} . \%$ of water, a mixture of ethanol and water is usually used as a feed in the ethanol dehydration. Moreover, a large amount of water (steam) is formed form the first step of ethanol dehydration (as shown in Equations (1) and (2)). The water certainly causes the catalyst deactivation in the following step of ethylene oligomerization over Ni/Al-HMS. It is necessary to remove the steam from the mixed gas before introducing the gas into the second reactor of ethylene oligomerization. A cold trap has been used for separating steam from other gas products in some reaction systems, such as in Fischer-Tropsch synthesis and in methanol dehydrogenation $[45,46]$. 
Figure 8 shows an illustration of the reaction process for the production of higher olefins from hydrous ethanol. The system contained two fixed-bed reactors and one cold trap. The two fixed-bed reactors were used to achieve ethanol dehydration and ethylene oligomerization, respectively. The cold trap was used to eliminate the steam from the mixed gas before the second step of ethylene oligomerization. The reaction pressure in the system was controlled at $1 \mathrm{MPa}$ by a back-pressure regulator.
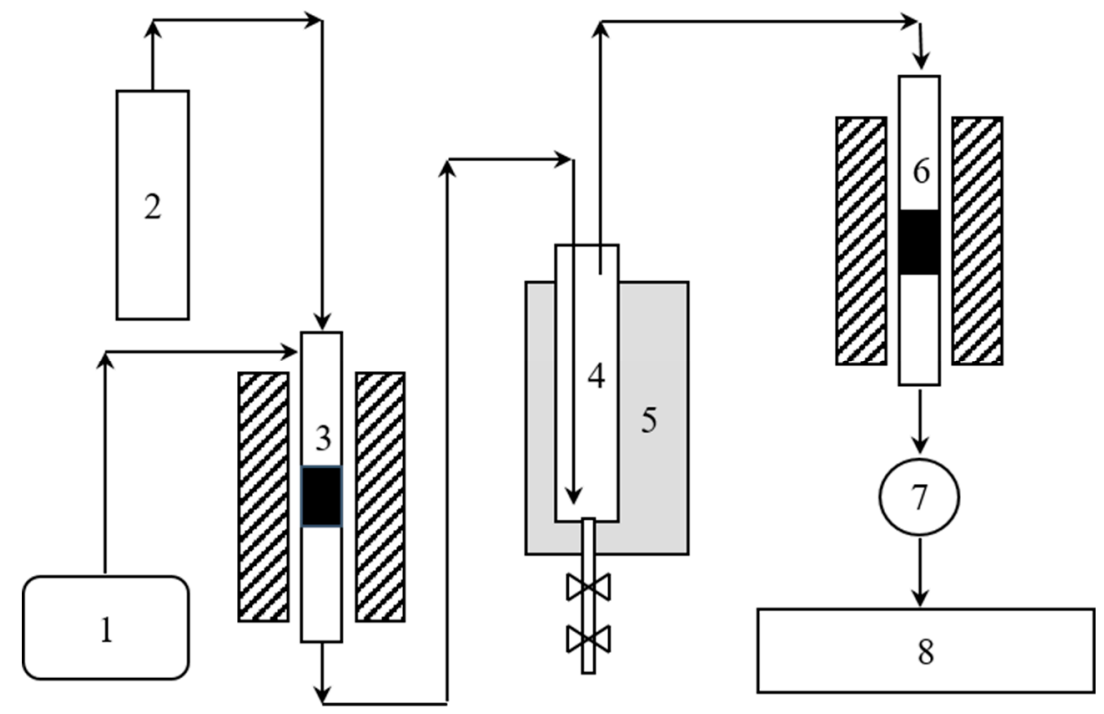

Figure 8. Illustration of reaction process for the production of higher olefins from hydrous ethanol.

(1) Ethanol-water tank, (2) Ar cylinder, (3) fixed-bed reactor A (for ethanol dehydration), (4) cold trap,

(5) ice-water tank, (6) fixed-bed reactor B (for ethylene oligomerization), (7) back-pressure regulator,

(8) on-line GC system.

During the reaction, a mixture of ethanol and water (containing $90 \mathrm{wt} . \%$ ethanol and $10 \mathrm{wt} . \%$ water) was fed from a tank by a high-pressured micro-pump to reactor A (packed with H-ZSM-5 catalyst) to achieve the dehydration of ethanol to ethylene at $300^{\circ} \mathrm{C}$. At the same time, Ar was also introduced in reactor A from a cylinder as a carry gas and an inner standard material for calculation. Then, the gas which flowed out from the outlet of reactor A was introduced into a cold trap (cooled by ice-water) to collect the formed water, unreacted ethanol, by-products diethyl ether and acetaldehyde from the first step of ethanol dehydration. Finally, the gas which flowed out from the cold trap was introduced into reactor $\mathrm{B}$ (packed with Ni/Al-HMS catalyst) to achieve the oligomerization of ethylene at $200{ }^{\circ} \mathrm{C}$.

Figure 9 shows the time course of olefin yield obtained from the system containing two fixed-bed reactors and one cold trap. A mixture of $90 \mathrm{wt} . \% \mathrm{C}_{2} \mathrm{H}_{5} \mathrm{OH}$ and $10 \mathrm{wt} . \% \mathrm{H}_{2} \mathrm{O}$ was fed in the reactor A with a rate of $0.13 \mathrm{~g} \mathrm{~min}^{-1}$. By assuming the yield of $\mathrm{C}_{2} \mathrm{H}_{4}$ was $92 \%$ over H-ZSM-5 (Table 2) in the reactor $\mathrm{A}$ and water was collected in the cold trap, the gas which introduced in the reactor $\mathrm{B}$ contained $52.4 \mathrm{~mL} \mathrm{~min}^{-1}$ of $\mathrm{C}_{2} \mathrm{H}_{4}$ and $10 \mathrm{~mL} \mathrm{~min}^{-1}$ of Ar. After reaction for $1 \mathrm{~h}$ in the two-step process, the yields of $\mathrm{C}_{2} \mathrm{H}_{4}, \mathrm{C}_{4} \mathrm{H}_{8}, \mathrm{C}_{6} \mathrm{H}_{12}, \mathrm{C}_{8} \mathrm{H}_{16}$, and $\mathrm{C}_{8+}$ were $1.8 \%, 35.7 \%, 22.5 \%, 22.1 \%$, and $7.6 \%$, respectively. Moreover, the yield of each olefin formed from the two-step process almost did not change after reaction for $8 \mathrm{~h}$ under a reaction pressure of $1 \mathrm{MPa}$. 


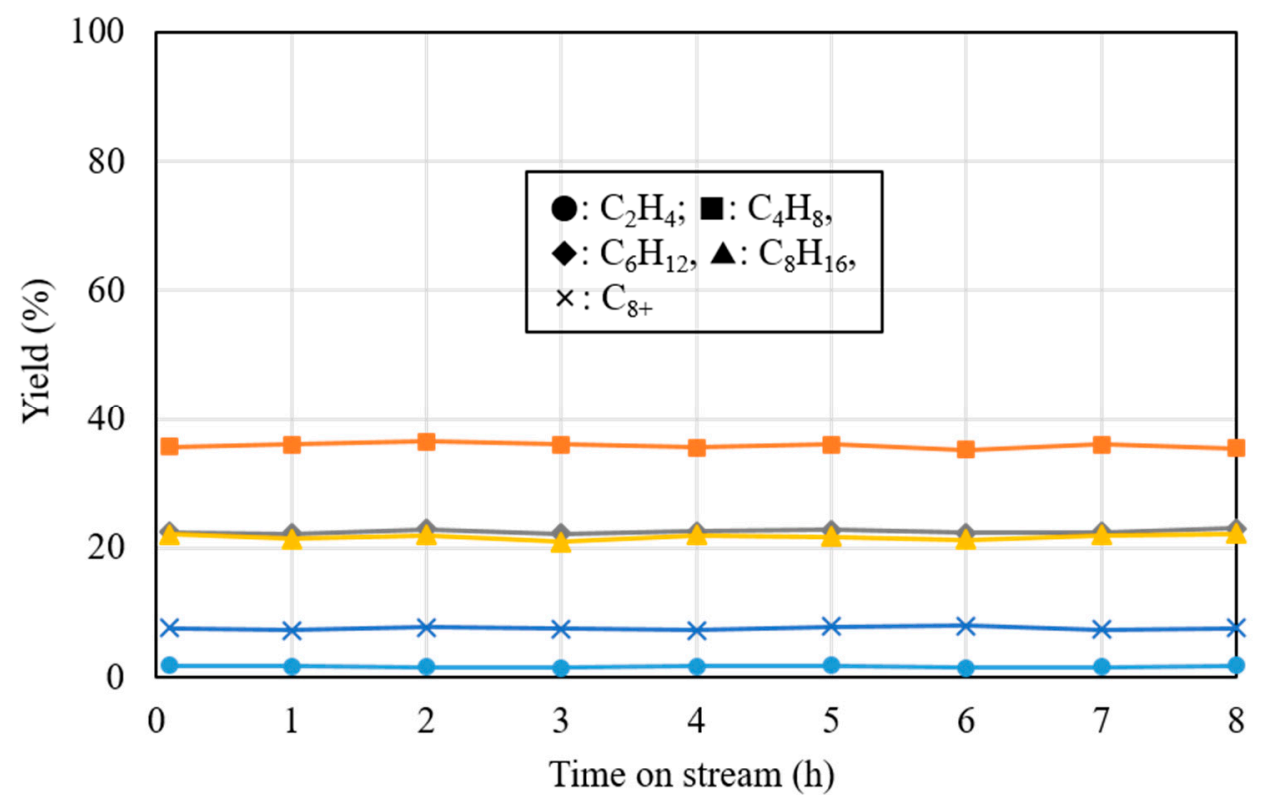

Figure 9. Time course of olefin yield obtained from the system containing two fixed-bed reactors and one cold trap. Reaction pressure: $1 \mathrm{MPa}$; liquid feed rate: $0.13 \mathrm{~g} \mathrm{~min}^{-1}$; liquid feed composition:

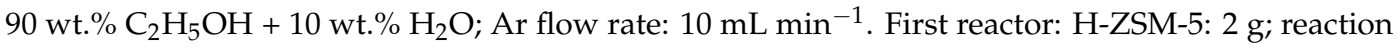
temperature: $300{ }^{\circ} \mathrm{C}$. Second reactor: $2 \mathrm{wt} . \% \mathrm{Ni} / \mathrm{Al}-\mathrm{HMS}: 2 \mathrm{~g}$; reaction temperature: $200{ }^{\circ} \mathrm{C}$.

\section{Experimental Section}

\subsection{Catalyst Syntheses}

HMS was prepared using dodecylamine as a template according to the method in the literature [16]. A clear solution of $\mathrm{Si}\left(\mathrm{OC}_{2} \mathrm{H}_{5}\right)_{4}(1.00 \mathrm{~mol})$ in ethanol $(6.54 \mathrm{~mol})$ was added to a stirring solution of dodecylamine $(0.27 \mathrm{~mol})$ and $\mathrm{HCl}(0.02 \mathrm{~mol})$ in water $(36.3 \mathrm{~mol})$. Then, the resulting gel was aged for $18 \mathrm{~h}$ at room temperature to form a crystalline templated product. The solid sample obtained by filtration was dried at $110{ }^{\circ} \mathrm{C}$ for $24 \mathrm{~h}$. Finally, the sample was calcined in air at $550{ }^{\circ} \mathrm{C}$ for $4 \mathrm{~h}$ to remove the template.

$\mathrm{Al}-\mathrm{HMS}$ which incorporated $\mathrm{Al}^{3+}$ ions in the HMS framework was prepared according to the method in the literature [19]. A clear solution containing $0.02 \mathrm{~mol}$ of $\mathrm{Al}\left(\text { iso- }-\mathrm{OC}_{3} \mathrm{H}_{7}\right)_{3}$ in $35 \mathrm{~mL}$ isopropyl alcohol and $0.2 \mathrm{~mol}$ of $\mathrm{Si}\left(\mathrm{OC}_{2} \mathrm{H}_{5}\right)_{4}$ in $80 \mathrm{~mL}$ ethanol (Al:Si $=1 / 10$ (molar ratio)) was heated at $70{ }^{\circ} \mathrm{C}$ for 4 $\mathrm{h}$ with vigorous stirring. Then, the solution was added to a solution containing $0.05 \mathrm{~mol}$ dodecylamine in $80 \mathrm{~mL}$ of water and $120 \mathrm{~mL}$ of ethanol. The solid sample obtained by filtration was dried at $110^{\circ} \mathrm{C}$ for $24 \mathrm{~h}$. Finally, the sample was calcined in air at $550^{\circ} \mathrm{C}$ for $4 \mathrm{~h}$ to remove the template.

$\mathrm{Al} / \mathrm{HMS}$ was prepared by grafting $\mathrm{Al}^{3+}$ ions on HMS external surface according to the method in the literature $[18,29]$. The HMS sample which calcined at $550{ }^{\circ} \mathrm{C}$ for $4 \mathrm{~h}$ was impregnated with $\mathrm{Al}\left(\text { iso-OC }{ }_{3} \mathrm{H}_{7}\right)_{3}$ in isopropyl alcohol (Al:Si $=1 / 10$ (molar ratio)), following by adding $25 \mathrm{~mL}_{2} \mathrm{O}$ to precipitate aluminum oxide. After stirring at room temperature for $3 \mathrm{~h}$, the solid product was filtrated, dried at $110{ }^{\circ} \mathrm{C}$ for $24 \mathrm{~h}$, and calcined in air at $550{ }^{\circ} \mathrm{C}$ for $4 \mathrm{~h}$.

Al-MCM-41 was prepared using cetyltrimethylammonium bromide (CTMABr) (25\% in water) as a template according to the method in the literature [14,15]. Tetramethylammonium silicate solution (with a molar ratio of $\mathrm{OH}^{-}$to $\mathrm{Si}$ of 0.26 ) was used as a silica source. The gel with a molar composition of $4 \mathrm{Si}: 0.4 \mathrm{Al}$ :CTMABr: $250 \mathrm{H}_{2} \mathrm{O}$ was heated at $100{ }^{\circ} \mathrm{C}$ for 4 days. As-synthesized Al-MCM-41 was obtained by filtration. The as-synthesized Al-MCM- 41 was dried at $110^{\circ} \mathrm{C}$ for $24 \mathrm{~h}$, and then calcined in air at $550^{\circ} \mathrm{C}$ for $4 \mathrm{~h}$ to remove the structurally incorporated template.

$\mathrm{Ni} / \mathrm{Al}-\mathrm{HMS}, \mathrm{Ni} / \mathrm{Al} / \mathrm{HMS}$, and $\mathrm{Ni} / \mathrm{Al} / \mathrm{MCM}-41$ were prepared by cationic exchange with $\mathrm{NH}_{4} \mathrm{NO}_{3}$ solution according to the method in the literature [34]. Al-HMS, Al/HMS, or Al/MCM-41 was treated with an aqueous solution of $\mathrm{NH}_{4} \mathrm{NO}_{3}$ to form $\mathrm{NH}_{4}$-type sample. Then, the $\mathrm{NH}_{4}$-type 
sample was added an aqueous solution of $\mathrm{Ni}\left(\mathrm{NO}_{3}\right)_{2}$ and was stirred at $50{ }^{\circ} \mathrm{C}$ for $3 \mathrm{~h}$ for exchange of $\mathrm{NH}_{4}{ }^{+}$with $\mathrm{Ni}^{2+}$. The exchange sample was dried at $110{ }^{\circ} \mathrm{C}$ for $24 \mathrm{~h}$ and calcined in air at $550{ }^{\circ} \mathrm{C}$ for $4 \mathrm{~h}$.

Acidic zeolite H-ZSM- 5 was prepared from Na-ZSM-5 (Tosho Co., Tokyo, Japan, $\mathrm{SiO}_{2} / \mathrm{Al}_{2} \mathrm{O}_{3}=$ 23.2, surface area: $322 \mathrm{~m}^{2} \mathrm{~g}^{-1}$ ) by ion-exchange. Na-ZSM-5 was treated with an aqueous solution of $\mathrm{NH}_{4} \mathrm{NO}_{3}$ to form $\mathrm{NH}_{4}-\mathrm{ZSM}-5$. The obtained $\mathrm{NH}_{4}-\mathrm{ZSM}-5$ was dried at $110{ }^{\circ} \mathrm{C}$ for $24 \mathrm{~h}$ and calcined in air at $550{ }^{\circ} \mathrm{C}$ for $4 \mathrm{~h}$ to form $\mathrm{H}-\mathrm{ZSM}-5$.

$\mathrm{Ni} / \mathrm{H}-\mathrm{ZSM}-5$ was prepared by an wetness impregnation of $\mathrm{H}-\mathrm{ZSM}-5$ in $\mathrm{Ni}\left(\mathrm{NO}_{3}\right)_{2}$ aqueous solution. The water solvent was removed by evaporating at $95^{\circ} \mathrm{C}$. After impregnation, the obtained solid sample was dried at $110{ }^{\circ} \mathrm{C}$ for $24 \mathrm{~h}$ and calcined in air at $550{ }^{\circ} \mathrm{C}$ for $4 \mathrm{~h}$.

\subsection{Catalyst Characterization}

The crystalline structure was characterized by an X-ray diffractometer (MAC Science MXP-18, MAC Science Co. Japan, Tokyo, Japan) operated at $40 \mathrm{kV}$ and $50 \mathrm{~mA}$ using $\mathrm{Cu} \mathrm{K} \alpha$ radiation. Fourier transform infrared spectra (FT-IR) measurement were recorded using a JASCO FT/IR spectrometer (JASCO Co., Osaka, Japan) under atmospheric conditions. A KBr pellets technology was used in the FT-IR measurement and the mass ratio of sample to $\mathrm{KBr}$ was 1:100. Temperature-programmed desorption of ammonia ( $\mathrm{NH}_{3}$-TPD) measurement was carried out using a BELCAT-B automatic system (Bell Co. Japan, Tokyo, Japan). A thermal conductivity detector (TCD) (Shimadzu Co., Kyoto, Japan) and an Omnistar Q-mass (Shimadzu Co., Kyoto, Japan) were used for detecting ammonia. In a typical $\mathrm{NH}_{3}$-TPD measurement, $0.05 \mathrm{~g}$ sample was pretreated in a He flow $\left(50 \mathrm{~mL} \mathrm{~min}{ }^{-1}\right)$ at $400{ }^{\circ} \mathrm{C}$ for $1 \mathrm{~h}$. After the furnace was cooled to $100{ }^{\circ} \mathrm{C}$, ammonia was adsorbed onto the sample's surface. The sample was evacuated at $100{ }^{\circ} \mathrm{C}$ for $1 \mathrm{~h}$ to eliminate the weakly physical adsorbed ammonia, and then $\mathrm{NH}_{3}$-TPD was recorded from 100 to $600{ }^{\circ} \mathrm{C}$ by heating the furnace with a rate of $8{ }^{\circ} \mathrm{C} \mathrm{min}-1$.

\subsection{Reactions and Instruments}

The oligomerization of ethylene was performed in a fixed-bed catalytic reaction system. The catalyst (24-60 meshes) was packed in a stainless-steel reactor (i.d.: $1 \mathrm{~cm}$; length: $40 \mathrm{~cm}$ ), and was pretreated in a $\mathrm{N}_{2}$ flow at $500{ }^{\circ} \mathrm{C}$ for $2 \mathrm{~h}$. After the reactor was cooled down to reaction temperature, a mixed gas containing $90 \% \mathrm{C}_{2} \mathrm{H}_{4}$ and $10 \%$ Ar was introduced in the reactor from a cylinder. The reaction pressure was $1 \mathrm{MPa}$ and the main reaction temperature was $200{ }^{\circ} \mathrm{C}$.

The dehydration of ethanol was performed in a fixed-bed catalytic reaction system. The catalyst (24-60 meshes) was packed in a stainless-steel reactor (i.d.: $1 \mathrm{~cm}$; length: $40 \mathrm{~cm}$ ), and was pretreated in a $\mathrm{N}_{2}$ flow at $500{ }^{\circ} \mathrm{C}$ for $2 \mathrm{~h}$. After the reactor was cooled down to the reaction temperature, a mixture of ethanol and water was fed in the reactor from a tank by a high-pressured micro-pump (Shimadzu LC-10, Shimadzu Co., Kyoto, Japan). At the same time, Ar was introduced in the reactor from a cylinder as a carrier gas and an inner standard material for calculation.

During the reaction, the products were continuously analyzed using an on-line GC analysis system. Inorganic gases were analyzed using a Shimadzu 14B TCD-GC (Shimadzu Co., Kyoto, Japan) equipped with a packed column filled by SHINCARBON. $C_{1}-C_{4}$ gas hydrocarbons were analyzed using a Shimadzu GC-2014 FID-GC (Shimadzu Co., Kyoto, Japan) equipped with a RT-QPLOT capillary column (Agilent Technologies Inc., Santaclara, CA, USA). Liquid organic compounds were analyzed using a Shimadzu GC-2014 FID-GC equipped a Stabilwax capillary column (Restek Co., Bellefont, PA, USA). A standard mixed gas (from a cylinder) with known concentration for each component was used to calculate the factors of gas samples. A standard mixed solution with known concentration for each component was prepared to calculate the factors of liquid organic compounds.

The carbon mass balance (before and after reaction) had an error less than $\pm 5 \%$ for the reactions carried out in this study. 


\section{Conclusions}

$\mathrm{Ni} / \mathrm{Al}-\mathrm{HMS}$ was an effective catalyst for the oligomerization of ethylene to higher olefins. The selectivity for $\mathrm{C}_{8} \mathrm{H}_{16}$ over $\mathrm{Ni} / \mathrm{Al}-\mathrm{HMS}$ was larger than that over the reported Ni/Al-MCM-41 catalyst. The existence of $\mathrm{Al}^{3+}$ ion in the neighborhood of $\mathrm{Si}^{4+}$ ion was important to improve the catalytic activity of $\mathrm{Ni} / \mathrm{Al}-\mathrm{HMS}$ in the oligomerization of ethylene. Ni sites were the main active sites in the ethylene oligomerization over Ni/Al-HMS. The primary product was $\mathrm{C}_{4} \mathrm{H}_{8}$ and the formed $\mathrm{C}_{4} \mathrm{H}_{8}$ was converted to larger olefins in the oligomerization of ethylene. The weak acid sites in Al-HMS had activity for the dimerization of the primary product $\mathrm{C}_{4} \mathrm{H}_{8}$ (formed on Ni sites) to $\mathrm{C}_{8} \mathrm{H}_{16}$, but they almost had no activity for the dimerization of $\mathrm{C}_{2} \mathrm{H}_{4}$ to $\mathrm{C}_{4} \mathrm{H}_{8}$. H-ZSM-5 was an effective catalyst for the dehydration of ethanol to ethylene, but a large amount of water in the feed caused the catalyst deactivation during the reaction. Using a reaction system containing two fixed-bed reactors (to achieve ethanol dehydration on H-ZSM-5 and ethylene oligomerization on Ni/Al-HMS) and one cold trap (to eliminate water), higher olefins were continuously produced by feeding a mixture containing $90 \mathrm{wt} . \%$ ethanol and $10 \mathrm{wt} . \%$ water.

Funding: This research received no external funding.

Conflicts of Interest: The authors declare no conflicts of interest.

\section{References}

1. Huber, G.W.; Iborra, S.; Corma, A. Synthesis of transportation fuels from biomass: Chemistry, catalysts, and engineering. Chem. Rev. 2006, 106, 1044-4098. [CrossRef] [PubMed]

2. Cesaro, A.; Belgiorno, V. Combined biogas and bioethanol production: Opportunities and challenge for industrial application. Energies 2015, 8, 8121-8144. [CrossRef]

3. Liu, Y.; Murata, K.; Inaba, M. Steam reforming of bio-ethanol to produce hydrogen over $\mathrm{Co} / \mathrm{CeO}_{2}$ catalysts derived from $\mathrm{Ce}_{1-\mathrm{x}} \mathrm{Co}_{\mathrm{x}} \mathrm{O}_{2-\mathrm{y}}$ precursors. Catalysts 2016, 6, 26. [CrossRef]

4. Sun, J.; Wang, Y. Recent advances in catalytic conversion of ethanol to chemicals. ACS Catal. 2014, 4, 1078-1090. [CrossRef]

5. Yao, G.; Staples, M.D.; Malina, R.; Tyner, W.E. Stochastic teno-economic analysis of alcohol-to-jet fuel production. Biotechnol. Biofuels 2017, 10, 18. [CrossRef] [PubMed]

6. Rossetti, I.; Compagnoni, M.; Finocchio, E.; Ramis, G.; Michele, A.D.; Mollot, Y.; Dzwigaj, S. Ethylene production via catalytic dehydration of diluted bioethanol: A step towards an integrated biorefinery. Appl. Catal. B Environ. 2017, 210, 407-420. [CrossRef]

7. Lee, J.H.; Lee, S.; Hong, S.B. Nanocrystalline H-RTH zeolite: An efficient catalyst for the low-temperature dehydration of ethanol to ethene. ChemSusChem 2018, 11, 2035-2039. [CrossRef] [PubMed]

8. Janlamool, J.; Jongsomjit, B. Catalytic ethanol dehydration to ethylene over nanocrystalline $x$ - and $\gamma-\mathrm{Al}_{2} \mathrm{O}_{3}$ catalysts. J. Oleo Sci. 2017, 66, 1029-1039. [CrossRef] [PubMed]

9. Sarazen, M.L.; Doskocil, E.; Iglesia, E. Effects of void environmental and acid strength on alkene oligomerization selectivity. ACS Catal. 2016, 6, 7059-7070. [CrossRef]

10. Moon, S.; Chae, H.J.; Park, M.B. Oligomerization of light olefins over ZSM-5 and beta zeolite catalysts by modifying textural properties. Appl. Catal. A Gen. 2018, 553, 15-23. [CrossRef]

11. Jin, F.; Fan, Y.; Yuan, M.; Min, F.; Wu, G.; Ding, Y.; Froment, G.F. Single-event kinetic modeling of ethene oligomerization on ZSM-5. Catal. Today 2018, 316, 129-141. [CrossRef]

12. Jan, O.; Song, K.; Dichiara, A.; Resende, F.L.P. Ethylene oligomerization over Ni-H $\beta$ heterogeneous catalysts. Ind. Eng. Chem. Res. 2018, 57, 10241-10250. [CrossRef]

13. Iwamoto, $\mathrm{M}$. Selective catalytic conversion of bio-ethanol to propene: A review of catalysts and reaction pathways. Catal. Today 2015, 242, 243-248. [CrossRef]

14. Kresge, C.T.; Leonowicz, M.E.; Roth, W.J.; Vartuli, J.C.; Beck, J.C. Ordered mesoporous molecular sieves synthesized by a liquid-crystal template mechanism. Nature 1992, 359, 710-712. [CrossRef]

15. Jing, H.; Guo, Z.; Ma, H.; Evans, D.G.; Duan, X. Enhancing the selectivity of benzene hydroxylation by tailoring the chemical affinity of the MCM-41 catalyst surface for the reactive molecules. J. Catal. 2002, 212, 22-32. [CrossRef] 
16. Tanev, P.T.; Chibwe, M.; Pinnavaia, T.J. Titanium-containing mesoporous molecular sieves for catalytic oxidation of aromatic compounds. Nature 1994, 368, 321-323. [CrossRef] [PubMed]

17. Pauly, T.R.; Liu, Y.; Pinnavaia, T.J.; Billinge, S.J.L.; Rieker, T.P. Textural mesoporosity and the catalytic activity of mesoporous molecular sieves with wormhole framework structures. J. Am. Chem. Soc. 1999, 121, 8835-8842. [CrossRef]

18. Liu, Y.; Kim, S.S.; Pinnavaia, T.J. Mesostructured aluminosilicate alkylation catalysts for the production of aromatic amine antioxidants. J. Catal. 2004, 225, 381-387. [CrossRef]

19. Mokaya, R.; Jones, W. Physicochemical characterization and catalytic activity of primary amine templated aluminosilicate mesoporous catalysts. J. Catal. 1997, 172, 211-221. [CrossRef]

20. Liu, Y.; Murata, K.; Inaba, M.; Mimura, N. Syntheses of Ti- and Al-containing hexagonal mesoporous silicas for gas-phase epoxidation of propylene by molecular oxygen. Appl. Catal. A Gen. 2006, 309, 91-105. [CrossRef]

21. Liu, Y.; Murata, K.; Inaba, M. Direct oxidation of benzene to phenol by molecular oxygen over catalytic systems containing $\mathrm{Pd}(\mathrm{OAc})_{2}$ and heteropolyacid immobilized on HMS or PIM. J. Mol. Catal. A Chem. 2006, 256, 247-255. [CrossRef]

22. Liu, Y.; Murata, K.; Inaba, M. Epoxidation of propylene with molecular oxygen in methanol over a peroxo-heteropoly compound immobilized on palladium exchanged HMS. Green Chem. 2004, 6, 510-515. [CrossRef]

23. Liu, Y.; Murata, K.; Inaba, M. Oxidation of propylene to propylene oxide with molecular oxygen by $\mathrm{Pd}(\mathrm{OAc})_{2} / \mathrm{Ti}-\mathrm{Al}-\mathrm{HMS} / \mathrm{CH}_{3} \mathrm{OH}$ catalyst system. Catal. Lett. 2004, 93, 109-112. [CrossRef]

24. Liu, Y.; Murata, K.; Inaba, M. Synthesis and catalytic activity of niobium-containing hexagonal mesoporous silica. Chem. Lett. 2003, 32, 992-993. [CrossRef]

25. Liu, Y.; Murata, K.; Inaba, M.; Mimura, N. Selective oxidation of propylene to propylene oxide by molecular oxygen over Ti-Al-HMS catalysts. Catal. Lett. 2003, 89, 49-53. [CrossRef]

26. Liu, Y.; Murata, K.; Inaba, M.; Mimura, N. Selective oxidation of propylene to acetone by molecular oxygen over $\mathrm{M}_{\mathrm{x} / 2} \mathrm{H}_{5-\mathrm{x}}\left[\mathrm{PMo}_{10} \mathrm{~V}_{2} \mathrm{O}_{40}\right] / \mathrm{HMS}\left(\mathrm{M}=\mathrm{Cu}^{2+}, \mathrm{Co}^{2+}, \mathrm{Ni}^{2+}\right)$. Catal. Commun. 2003, 4, 281-285. [CrossRef]

27. Liu, Y.; Suzuki, K.; Hamakawa, S.; Hayakawa, T.; Murata, K.; Ishii, T.; Kumagai, M. Highly active methanol decomposition catalyst derived from Pd-hydrotalcite dispersed on mesoporous silica. Catal. Lett. 2000, 66, 205-213. [CrossRef]

28. Liu, Y.; Suzuki, K.; Hamakawa, S.; Hayakawa, T.; Murata, K.; Ishii, T.; Kumagai, M. Catalytic methanol decomposition at low temperature over Pd catalyst derived from mesoporous silica carried Pd-hydrotalcite. Chem. Lett. 2000, 486-487. [CrossRef]

29. Liu, Y.; Murata, K.; Okabe, K.; Hanaoka, T.; Sakanishi, K. Synthesis of Zr-grafted SBA-15 as an Effective Support for Cobalt Catalyst in Fischer-Tropsch Synthesis. Chem. Lett. 2008, 37, 984-985. [CrossRef]

30. Heveling, J.; Nicolaides, C.P.; Scurell, M.S. Catalysts and conditions for the highly efficient, selective and stable heterogeneous oligomerization of ethylene. Appl. Catal. A Gen. 1998, 173, 1-9. [CrossRef]

31. Sohn, J.R.; Park, W.C.; Park, S.E. Characterization of nickel sulfate supported on $\mathrm{SiO}_{2}-\mathrm{Al}_{2} \mathrm{O}_{3}$ for ethylene dimerization and its relationship to acidic properties. Catal. Lett. 2002, 81, 259-264. [CrossRef]

32. Zhang, Q.; Kantcheva, M.; Dalla Lana, I.G. Oligomerization of ethylene in a slurry reactor using a nickel/sulfate alumina catalyst. Ind. Eng. Chem. Res. 1997, 36, 3433-3438. [CrossRef]

33. Hulea, V.; Fajila, F. Ni-exchanged AlMCM-41-An efficient bifunctional catalyst for ethylene oligomerization. J. Catal. 2004, 225, 213-222. [CrossRef]

34. Tanaka, M.; Itadani, A.; Kuroda, Y.; Iwamoto, M. Effect of pore size and nickel content of Ni-MCM-41 on catalytic activity for ethene dimerization and local structures of nickel ions. J. Phys. Chem. C 2012, 116, 5664-5672. [CrossRef]

35. Lacarriere, A.; Robin, J.; Swierczynski, D.; Finiels, A.; Fajula, F.; Luck, F.; Hules, V. Distillate-range products from non-oil-based sources by catalytic cascade reactions. ChemSusChem 2012, 5, 1787-1792. [CrossRef] [PubMed]

36. Moussa, S.; Arribas, M.A.; Concepcion, P.; Martinez, A. Heterogeneous oligomerization of ethylene to liquids on bifunctional Ni-based catalysts: The influence of support properties on nickel speciation and catalytic performance. Catal. Today 2016, 277, 78-88. [CrossRef]

37. Andrei, R.D.; Popa, M.I.; Fajula, F.; Hulea, V. Hwtergeneous oligomerization of ethylene over highly active and stable Ni-AlSBA-15 mesoporous catalysts. J. Catal. 2015, 323, 76-84. [CrossRef] 
38. Lallemand, M.; Finiels, A.; Fajula, F.; Hulea, V. Continuous stirred tank reactor for ethylene oligomerization catalyzed by NiMCM-41. Chem. Eng. J. 2011, 172, 1078-1082. [CrossRef]

39. Wu, P.; Tatsumi, T.; Komatsu, T.; Yashima, T. A novel titanosilicate with MWW structure: II. catalytic properties in the selective oxidation of alkenes. J. Catal. 2001, 202, 245-255. [CrossRef]

40. Park, K.C.; Yim, D.J.; Ihm, S.K. Characteristics of Al-MCM-41 supported Pt catalysts: Effect of Al distribution in Al-MCM-41 on its catalytic activity in naphthalene hydrogenation. Catal. Today 2002, 74, 281-290. [CrossRef]

41. Lallemand, M.; Finiels, A.; Fajula, F.; Hulea, V. Nature of the active sites in ethylene oligomerization catalyzed by Ni-containing molecular sieves: Chemical and IR spectral investigation. J. Phys. Chem. C 2009, 113, 20360-20364. [CrossRef]

42. Harvey, B.G.; Quintana, R.L. Synthesis of renewable jet and diesel fuels from 2-ethyl-1-hexene. Energy Environ. Sci. 2010, 3, 352-357. [CrossRef]

43. Yu, Y.; Zhang, M. Dehydration of ethanol to ethylene. Ind. Eng. Chem. Res. 2013, 52, 9505-9514.

44. Zhang, X.; Wang, R.; Yang, X.; Zhang, F. Comparison of four catalysts in the catalytic dehydration of ethanol to ethylene. Microporous Mesoporous Mater. 2008, 116, 210-215. [CrossRef]

45. Liu, Y.; Hanaoka, T.; Miyazawa, T.; Murata, K.; Okabe, K.; Sakanishi, K. Fischer-Tropsch synthesis in slurry-phase reactors over $\mathrm{Mn}$ - and $\mathrm{Zr}$-modified $\mathrm{Co} / \mathrm{SiO}_{2}$ catalysts. Fuel Process. Technol. 2009, 90, 901-908. [CrossRef]

46. Liu, Y.; Murata, K.; Inaba, M.; Takahara, I. Synthesis of ethanol from methanol and syngas through an indirect route containing methanol dehydrogenation, DME carbonylation, and methyl acetate hydrogenolysis. Fuel Process. Technol. 2013, 110, 206-213. [CrossRef]

(C) 2018 by the author. Licensee MDPI, Basel, Switzerland. This article is an open access article distributed under the terms and conditions of the Creative Commons Attribution (CC BY) license (http:/ / creativecommons.org/licenses/by/4.0/). 